\title{
Dampak Non-target Pengendalian Hayati Spesies Asing terhadap Ekosistem
}

\author{
DAMAYANTI BUCHORI \\ Departemen Proteksi Tanaman, Institut Pertanian Bogor. \\ dami@indo.net.id
}

(diterima Juni 2006, disetujui Februari 2007)

\begin{abstract}
Non target impact of classical biological control of exotic species in the ecosystem. Classical biological control has been hailed as a successful control method of many exotic species of pests. However, recently this meth od of control has been questioned due to several cases of non target impact. Non target impact can occur two ways, i.e. direct non target impact when there is a host shift of the bioagents (e.g. changes in preferences), and the indirect non target impact which can occur through, among others, food web subsides that will change the overall interactions of many species within an ecosystem. The aim of this paper is to understand the interactions between introduced exotic agents (e.g. insects) toward local diversity, e.g. what are the implications of the interactions toward local biodiversity? Are there non target and indirect impacts of these introductions in Indonesia? The discussions covers the concept of biological control and conservation issues that should be taken into consideration, particularly in the context of insect conservation and impacts of classical biological control on island diversity.
\end{abstract}

KEYWORDS : Biological control, non target, exotic species, classical, ecosystem

\section{PENDAHULUAN}

Globalisasi dan pergerakan manusia telah menyebarkan berbagai jenis tumbuhan dan hewan jauh dari sumber asalnya. Akibat dari persebaran dengan bantuan manusia ini, ribuan species tumbuhan saat ini telah mapan secara permanen pada zona fitogeografi yang secara evolusi normal sebenarnya tidak akan pernah terjadi (Wilson 1988). Salah satu jenis tumbuhan dan hewan yang banyak melintas batas geografis adalah spesies asing invasif. Ketika spesies asing tersebut masuk ke habitat baru, daya merusaknya yang tinggi sering menyebabkan kehancuran habitat, karena terjadinya homogenisasi biotik dan punahnya keanekaragaman lokal. Salah satu cara yang telah lama dikenal untuk mengatasi spesies asing invasif ini adalah pengendalian hayati klasik (Huffaker et al. 1976). Saat ini. dengan berkembangnya ilmu ekologi, beberapa teori yang terkait pengendalian hayati klasik telah dipertanyakan oleh beberapa peneliti (Pearson \& Callaway, 2003). Tulisan 
ini mengulas beberapa perkembangan terbaru tersebut.

\section{SPESIES ASING DAN PENGENDALIAN HAYATI}

Saat ini telah cukup banyak spesies asing yang mendominasi habitat baru dan menimbulkan ancaman terhadap keberadaan spesies lokal. Spesies tersebut sering disebut dengan spesies asing dan sering bersifat invasif (invasive alien species), contohnya adalah tumbuhan gulma eceng gondok (Eichhornia crassipes (Mart.) Solms.), dan kirinyu (Chromolaena odorata (L). King \& Robinson. Dengan daya sebar dan kemampuan reproduksi yang tinggi, spesies asing invasif ini dapat mengancam kelestarian spesies lokal dan menyebabkan homogenisasi biotic (biotic homogenization) (Olden et al. 2004). Beberapa spesies asing invasif telah dibuktikan dapat mengubah jalur evolusi dari spesies lokal melalui kompetisi, pemindahan relung, hibridisasi, dan akhirnya bahkan kepunahan (Mooney \& Cleland 2001).

Salah satu usaha yang telah dilakukan untuk mengatasi spesies asing invasif adalah dengan menggunakan tehnik pengendalian hayati klasik (classical biological control), dimana suatu agens hayati (misal serangga) diintroduksi dari negara asal spesies asing ke suatu daerah baru yang telah diserang oleh spesies asing itu (McFadyen 1998). Tindakan seperti ini telah terbukti berhasil di beberapa tempat (De Loach 1991: Mack et al. 2000). Dengan adanya pengendalian hayati ini, diharapkan bahwa spesies tanaman lokal tidak akan punah. Gambar 1 mengilustrasikan hubungan antara agens hayati, spesies invasif, serta tanaman lokal yang mendapatkan manfaat dari introduksi tersebut. Model konseptual dari pengendalian hayati sebenarnya diawali dari teori predator-mangsa (van Driesche and Bellows 1996) yang berlandaskan pemahaman bahwa species asing menjadi invasif karena ketiadaan musuh alaminya. Model ini memprediksikan adanya pengaruh negatif yang langsung dari agens hayati terhadap spesies invasif, dan adanya pengaruh tidak langsung yang positif dari hubungan tadi, terhadap keberadaan spesies lokal.

\section{DAMPAK NON-TARGET PENGENDALIAN HAYATI KLASIK}

Sebenarnya pengendalian hayati klasik ini tidak lepas dari resiko. Resiko ini biasa disebut dengan dampak non target dari pengendalian hayati (non target impact of biological control) (Pearson 2000, Pearson \& Callaway 2003). Dampak non target bisa terjadi melalui dua cara, yaitu pertama direct non target impact (dampak non target yang langsung), yaitu bila terjadi pergeseran preferensi terhadap tanaman inang dari agens 
hayati (host shift), dan kedua, indirect non-target impact (dampak non target yang tidak langsung).

Gambar 1 menunjukkan bahwa model pengendalian selama ini terfokus pada pengaruh negatif yang langsung dari agens hayati terhadap gulma invasif dan pengaruh tidak langsung yang positif dari interaksi tersebut terhadap tanaman lokal, tanpa memperhatikan interaksi lainnya secara utuh (Pearson \& Callaway 2003).

Salah satu contoh kasus mengenai pergeseran inang telah ditemukan pada pengendalian Opuntia oleh Cactoblactis cactorum. Introduksi C.cactorum dari Argentina, yaitu ngengat pengorok batang kaktus, telah berhasil mengendalikan penyebaran Opuntia di Australia. Walaupun demikian, ternyata beberapa penelitian sesudahnya menunjukkan bahwa keberadaan $C$. cactorum di Florida
Keys, USA mengancam keberadaan kaktus endemic di Amerika Serikat (Simberloff \& Stiling 1996, 1998), karena ternyata $C$. cactorum ini cukup agresif menyerang kaktus endemic di Amerika Serikat. Contoh lainnya dijumpai pada introduksi kumbang Larinus planus (F) dari Eurasia ke Amerika Serikat untuk mengendalikan gulma Cirsium arvense, yang ternyata menyerang Cirsium undulatum (Louda \& O'Brien 2002).

Selama ini, konsep dan praktek pengendalian hayati klasik yang berkembang di lapang terlalu menitik beratkan pada pengaruh agens hayati terhadap gulma, tetapi kurang memperhatikan dampak dari introduksi agens hayati terhadap jejaring makanan (Pearson \& Callaway 2003, lihat Gambar 1). Hal ini disayangkan karena sebenarnya masih banyak pengaruh tidak langsung dari introduksi agens hayati yang selama ini

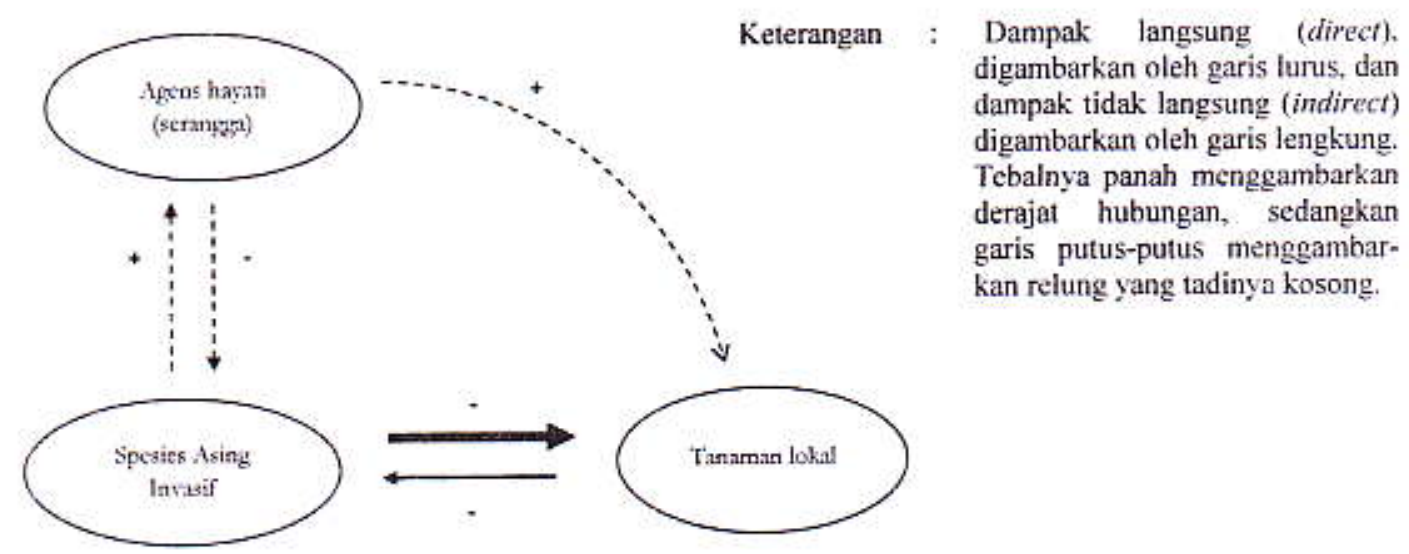

Gambar 1. Model pengendalian gulma invasif oleh agens hayati (serangga) dan hubungannya dengan tanaman lokal (Pearson \& Callaway 2003). 
lepas dari perhatian kita, yaitu yang dikenal sebagai indirect non target effect dari pengendalian hayati klasik, dan dapat muncul dalam beberapa bentuk: a) pergantian ekologis (ecological replacement), dan b). Interaksi jejaring makanan (food web interactions).

\section{PERGANTIAN EKOLOGIS (ECOLOGICAL REPLACEMENT)}

Dampak non target yang tidak langsung dapat terjadi melalui skema pergantian ekologis bila agens hayati mengendalikan spesies asing yang ternyata telah mapan dan mengambil alih suatu relung yang khusus di dalam ekosistem. Contoh yang dapat diungkapkan disini adalah pengendalian spesies asing kelinci Eropa (Oryctolagus cuniculus) di Inggris dengan virus Myxoma ternyata menyebabkan punahnya kupu-kupu biru Maculina arion. Apa yang terjadi? Sebuah penelitian mengungkapkan adanya hubungan simbiosis mutulaistis antara kupu $M$. arion dengan semut Myrmica sabuleti. Kupu $M$. arion memerlukan semut untuk perkembangan larvanya, sedangkan semut Myrmica memerlukan ladang yang terbuka untuk membuat sarangnya. Selama ini, keberadan kelinci memastikan adanya ladang terbuka bagi semut untuk membuat sarangnya. Dengan matinya kelinci, maka ladang terbuka berkurang, sehingga mengurangi populasi semut yang pada akhirnya juga mengurangi populasi kupu $M$. arion (Pearson \& Callaway 2003). Contoh kasus ini memang masih merupakan kasus yang jarang, tetapi bisa diduga bahwa permasalahan yang diilustrasikan ini dapat meningkat di masa mendatang dengan makin banyaknya spesies asing yang mapan di habitat barunya.

\section{SUBSIDI JEJARING MAKANAN (FOOD WEB SUBSIDIES)}

Dampak non target yang tidak langsung dapat terjadi pula melalui mekanisme food web subsidies. Kondisi ini akan muncul bila ternyata agens hayati mampu bertahan dan mapan berada di lapang, tetapi tidak berhasil mengendalikan populasi gulma (Pearson \& Callaway 2003, Louda and O'Brien 2006). Food web subsidies (subsidi jejaring makanan) terjadi bila ternyata agens hayati yang gagal mengendalikan gulma justru memperkaya jejaring makanan dan dapat memberikan pengaruh bottom up yang menghubungkan gulma invasif dengan organisme lokal/asli lainnya melalui jejaring makanan. Pada kondisi demikian, agens hayati bisa tumbuh dengan pesat karena makanannya banyak, sedikit kompetisi, dan tidak ada musuh alaminya. Sebagai contoh, pengendalian hayati terhadap gulma knapweed dengan menggunakan lalat puru Urophora spp ternyata gagal menekan populasi gulma tersebut. Walaupun demikian, ternyata lalat 
puru tersebut mampu beradaptasi dan hidup dengan mapan di habitat barunya. Keberadaan lalat puru ini justru meningkatkan populasi tikus Peromyscus maniculatus (Pearson et al. 2000), karena tikus ini justru mendapat sumber makanan dari keberadaan lalat puru pada tanaman gulma tersebut. Food web subsidies seperti ini mampu mengubah dan merestrukturisasi interaksi komunitas dan perlu mendapat perhatian khusus di Indonesia.

\section{ADAKAH DAMPAK NON- TARGET PENGENDALIAN HAYATI GULMA DI INDONESIA?}

Indonesia telah beberapa kali melakukan introduksi spesies asing untuk mengendalikan gulma invasif, diantaranya adalah pemanfaatan kumbang Neochetina eichhorniae Warner untuk mengendalikan eceng gondok (Eichhorniae crassipes) (Kasno et al. 2001) yang diintroduksi dari Florida dan dilepas pada tahun 1979 di Jawa Barat dan Jawa Tengah; serta introduksi Cecidochares connexa Macquart untuk mengendalikan gulma kirinyuh, Chromolaena odorata (L) King \& Robinson, yang dilepas tahun 1995 di Jawa Barat. Beberapa penelitian yang telah dilakukan oleh Kartosuwondo et al. 2006; Sapdi 2007, menunjukkan bahwa agens hayati tersebut telah mapan berada di lapangan, tetapi tidak mampu menekan populasi gulma invasif tersebut.
Kondisi ini menarik dan patut mendapat perhatian lebih jauh dari para praktisi pengendalian hayati. Apakah food web subsidies dan ecological replacement telah terjadi di lapangan? Jika belum, mungkinkah terjadi? Bagaimanakah perubahan struktur komunitas yang telah terjadi dengan mapannya agens hayati tersebut di lapang? Jika dilakukan pengendalian akankah ada dampak non target yang bisa diprediksi? Masih banyak pertanyaan yang harus dijawab oleh para praktisi pengendalian hayati.

\section{KESIMPULAN}

Perkembangan ilmu telah menunjukkan bahwa memasukkan musuh alami asing dalam rangka mengendalikan spesies asing invasive (classical biological control) dapat mempengaruhi lingkungan karena adanya kompleksitas jejaring makanan. Untuk menjalankan pengendalian hayati yang aman, diperlukan penelitian penelitian dasar yang menganalisis lebih jauh interaksi antar trophic level dalam jejaring makanan disuatu habita.

\section{DAFTAR PUSTAKA}

De Loach CJ. 1991. Past successes and current prospects in biological control of weeds in the USA and Canada. Nat. Areas $J$. 11:129-142.

Huffaker, CB, Luck, RF, Messenger, PS. 1976. The ecological basis of biological control. Proc. XV Int. Cong. Ent. 1976:560-586 
Kasno, Putri ASR, Widayanti S, Sunjaya. 2001. Establishrnent of Neochetina spp: their pattern of local dispersal and age structure at release site. Biotropia 17:1829.

Kartosuwondo U, Buchori D, Tjitrosemito S. 2006. Spesies eksotik: implikasi spesies eksotik terhadap keanekaragaman hayati dan struktur komunitas serangga pada berbagai ekosistem. Laporan Hibah Penelitian Tim Pascasarjana. IPB.

Louda S, O'Brien CW. 2002. Unexpected ecological effects of distributing the exotic weevil, Larinus planues (F), for the biological control of Canada Thistle. Conservation Biology 16(3): 717-727.

Mack RN, Simberloff D, Lonsdale WM, Evans H, Clout M, Bazzaz F. 2000. Biotic invasions: causes, epidemiology, global consequences and control. Ecol. Appl. 10: 689-710.

McFadyen RE. 1998. Biological control of weeds. Annu. Rev. Entomol, 43:369-393.

Mooney HA, Cleland EE. 2001. The evolutionary impact of invasive species. PNAS. 98 (10): 5446-5451.

Olden JD, Poff NL, Douglas MR. Douglas ME, Faucsh KD, 2004. Ecological and evolutionary consequences of biotic homogenization. TREE 19(1):18-24

Pearson DE, McKelvey KS, Ruggiero LF. 2000. Non target effects of an introduced biological control agent on deer mouse ecology. Oecologia 122:121-128.

Pearson DE, Callaway RM. 2003. Indirect effects of host-specific biological control agents TREE 18: 456-461.

Sapdi. 2007. Implikasi Kebcradaan spesies asing invasive eceng gondok dan agens hayati Neochetina terhadapa komunitas tumbuhan akuatik dan serangga. [Disertasi] .Bogor: IPB.

Simberloff D, Stiling P. 1996. How risky is biological control? Ecology 77:19651974.

Simberloff D, Stiling P. 1998. How risky is biological control? Reply. Ecology 79: 1834-1836

Van Driesche RG, Bellows TS. 1996. Biological Control. Chapman and Hall.

Wilson EO. 1988. The Current State of Biological Diversity. Didalam Wilson EO, Peter FM (ed). Biodiversity. Washington DC: National Academy Press 